\title{
Rice Yield Components under Water Stress Imposed at Different Growth Stages
}

\author{
Germani Concenço ${ }^{1}$, José Maria Barbat Parfitt ${ }^{1}$, Ivana Santos Moisinho ${ }^{2}$, Marcos Valle Bueno ${ }^{2}$, \\ Jaqueline Trombetta da Silva ${ }^{2} \&$ Samara Emerim Concenço ${ }^{3}$ \\ ${ }^{1}$ EMBRAPA Temperate Climate, Brazilian Agricultural Research Corporation, Pelotas, RS, Brazil \\ ${ }^{2}$ Federal University of Pelotas, Pelotas, RS, Brazil \\ ${ }^{3}$ Federal Institute of Santa Catarina, Campus Sombrio, Sombrio, SC, Brazil \\ Correspondence: Jaqueline Trombetta da Silva, Universidade Federal de Pelotas, Faculdade de Agronomia \\ Eliseu Maciel, Departamento de Solos, Av. Eliseu Maciel, CEP: 96050-500, Capão do Leão, RS, Brazil, Tel: \\ 55-53-3275-8444. E-mail: jak_trombetta@hotmail.com
}

$\begin{array}{ll}\text { Received: December 5, } 2017 & \text { Accepted: January 18, } 2018 \quad \text { Online Published: February 15, } 2018 \\ \text { doi:10.5539/jas.v10n3p290 } & \text { URL: https://doi.org/10.5539/jas.v10n3p290 }\end{array}$

\begin{abstract}
We aimed to assess rice yield components as function of water stress imposed at distinct crop growth stages under greenhouse, in randomized block design under factorial scheme $3 \times 4+1$, with four replications. The factor "A" was the growth stage in which water stress was imposed, being (a) vegetative, (b) reproductive 1, and (c) reproductive 2; factor "B" was four levels of water stress $(0-200 \mathrm{kPa})$. There was also an additional treatment consisting of a flooded check. Water was replenished to saturation every time the threshold stress was reached. At the end of the cycle, all panicles were counted and collected, per plant, for further analysis. In the lab, grains per panicle were counted, being classified either as whole kernel or aborted grains, whose results were used for obtaining sterility percentage. Whole kernel grains were weighted for obtaining the 1000 grains weight for each treatment, and the consequent plant grain yields. Number of panicles was not affected when stress was imposed after panicle initiation, but when imposed at tillering it was reduced; at grain filling, water stress promoted grains sterility higher than $90 \%$; grain weight was only reduced when carbohydrates were directed to root formation in detriment of grain filling; lower rice grain yield per plant was observed even when treatments were maintained above $10 \mathrm{kPa}$ all along the cycle, compared to the flooded treatment.
\end{abstract}

Keywords: Oryza sativa, productivity, water demand

\section{Introduction}

Rice is considered a staple food for approximately half the world's population, cultivated in about 112 countries, with $90 \%$ of the global production concentrated in Asia. In Brazil, about 3 million hectares of rice are cultivated annually and the cereal is important part of Brazilians diet, regardless of social class (Gomes \& Magalhães Jr., 2004).

Water demand in flooded rice is higher than the required for crops traditionally sprinkler irrigated, such as corn or soybeans. This raises some questions regarding water use efficiency and environmental impact caused by rice cultivation.

Sprinkler irrigation, by pivot or linear hardware, continues to be tested for rice cultivation. Some researchers (Parfitt et al., 2011) report 50\% water economy when rice is grown under pivots compared to flooding. This is mainly observed when the system is installed in highly sloped areas or in fields with scarce water.

In order to support rice growing systems which demand less water and help environmental conservation, there is need to understand how rice grain yield is affected by water stress when it is imposed at different phenological crop stages, as rice yield components are the determiners of its productivity (Gomes \& Magalhães Jr., 2004).

Water content in plants is important for keeping hydration, maintaining cell turgidity for structure and growth; it is also responsible for nutrient transportation and organic compounds into the plant, which are the greatest determiners of crop productivity (Gurevitch, Scheiner, \& Fox, 2009). For Samonte, Wilson, Mcclung, and Tarpley (2001), the soil moisture stress affects various physiological processes as photosynthesis and 
transpiration, reducing growth and grain filling. Zain, Ismail, Puteh, Mahmood, and Islam (2014) reports that water stress affects the grain yield, total plant biomass, 1000-grain weight, tiller and panicle number and plant height.

However, to support water management decisions, it is necessary to know the real effects of water stress levels on rice grain yield and its components. Thus, we aimed with this study to assess rice yield components as function of water stress levels imposed at different crop developmental stages.

\section{Material and Method}

\subsection{Location, Experimental Design, Treatments}

The experiment was installed into a greenhouse, owned by Embrapa Clima Temperado, at the city of Pelotas, Brazil. We used a randomized complete-block design with plots arranged under factorial scheme, $3 \times 4+1$, with four replications. The chosen rice variety for the study was BRS-Querencia, with early cycle (Embrapa, 2005). The factor "A" comprised the growth stage in which the water stress was to be imposed, being (a) vegetative (tillering start through panicle differentiation), (b) reproductive 1 (panicle differentiation through anthesis), and (c) reproductive 2 (anthesis through ripening start). Factor "B" was composed by the four levels of water stress. There was also an additional treatment, which consisted of continuously flooded vases.

The reproductive stage in rice starts at panicle initiation (Sosbai, 2014), but as this stage is difficult to be determined we decided to use the panicle differentiation as the indicator of the reproductive stage. According to Carli, Steinmetz, Streck, Marchezan, and Silva (2014), panicle initiation (PI) and differentiation (PD) differ only in approximately 4 days.

\subsection{Water Stress Management}

From emergence to the emission of the first tillers, all plots were maintained below $10 \mathrm{kPa}$ in tension-including those plots which were to be flooded after tillering emission. When the treatment was at the water threshold level, irrigation to saturation was applied. Treatments not under stress were kept below $10 \mathrm{kPa}$. Treatments are presented in Table 1.

Table 1. Water stress levels (treatments) studied under controlled environment aiming to assess the impact on crop productivity.

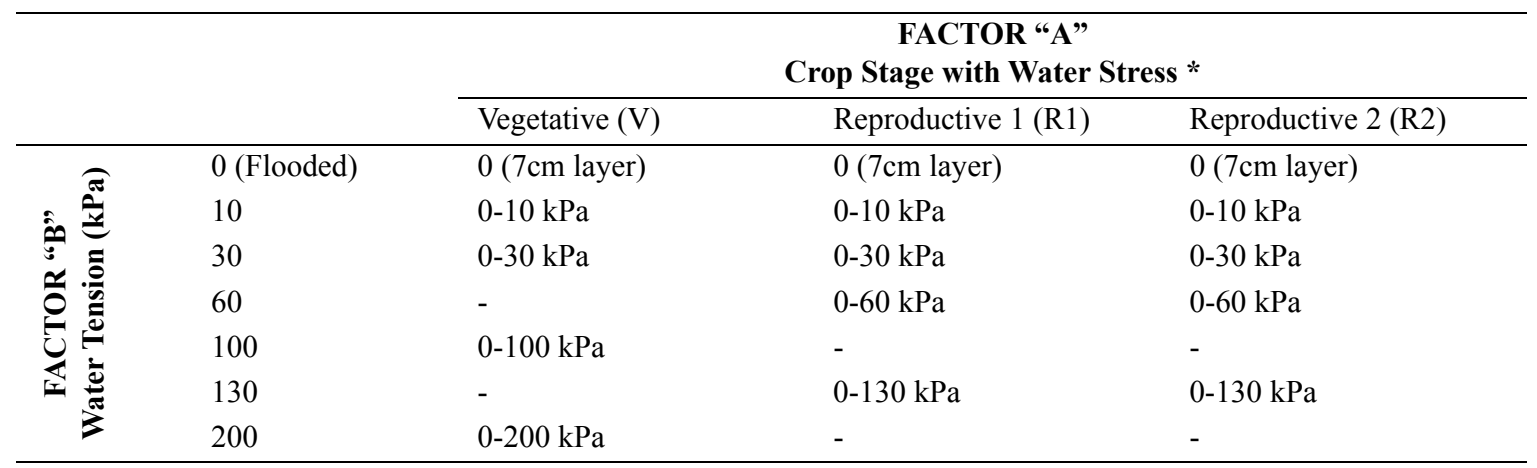

Note. * When not under the moment where the stress was to be applied, all treatments (except the flooded check) were kept below $10 \mathrm{kPa}$.

\subsection{Experimental Units}

The experimental units were plastic vases with $12 \mathrm{~L}$, fulfilled with $10 \mathrm{~kg}$ of soil which was corrected and fertilized previously to the experiment installation. Soil $\mathrm{pH}$ is usually not problematic for rice because the water is usually enough to correct the $\mathrm{pH}$ on flooding onset, but as most plots were not supposed to be submitted to flooding, soil $\mathrm{pH}$ was corrected for the experiment. Seven rice seeds were put into each experimental plot, and after emergence the five most homogeneous plants were maintained.

\subsection{Water Stress Monitoring}

The soil water tension was registered by sets of electro-tensiometers, with one sensor per plot at $10 \mathrm{~cm}$ depth. Water tension in all plots was recorded once per hour. Sensor readings were corrected as function of soil temperature, which was obtained by Watermark temperature sensors installed into the plots also at $10 \mathrm{~cm}$ depth. 
Soil water tension was verified manually twice a day. When it reached the treatment level, water was added to take soil back to saturation. The amount of added water was determined through a soil moisture retention curve (Figure 1).

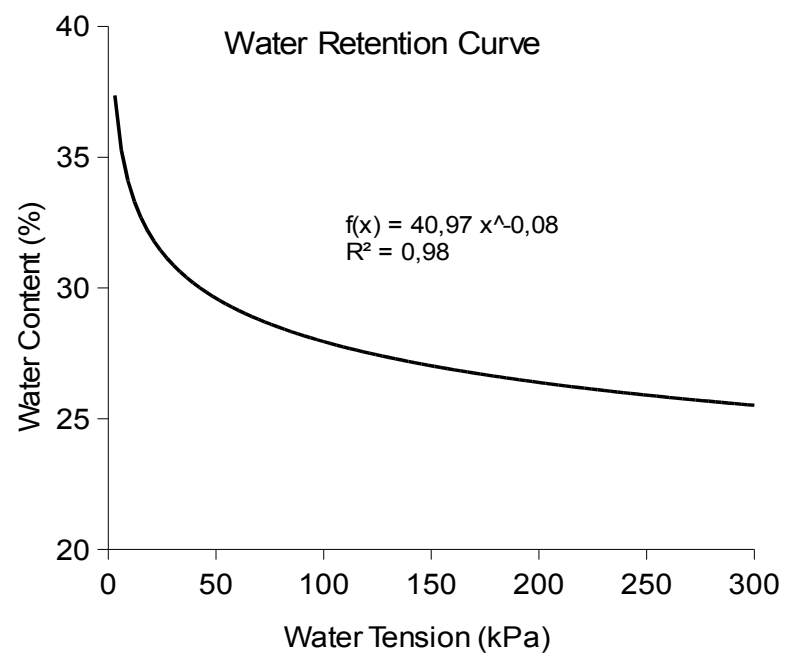

Figure 1. Water retention curve for the soil used at the experiment under controlled environment. Embrapa Clima Temperado, Pelotas-RS, Brazil, 2016

\subsection{Environmental Conditions and Water Demand}

The daily maximum and minimum temperature and air humidity into the greenhouse along the duration of the experiment are shown in Figures $2 \mathrm{~A}$ and $2 \mathrm{~B}$, respectively. The evapotranspiration $\left(\mathrm{ET}_{0}\right)$ was estimated as an additional way to help defining when the plots would most probably reach the threshold water level and avoid losing the timing for water application. $\mathrm{ET}_{0}$ was estimated by using the Hargreaves method (Figure 2C), based on daily temperature ranges (Figure 2A).

\subsection{Sampling and Data Collection}

At the end of the cycle, all panicles were counted and collected, per plant, for further analysis. In the lab, grains per panicle were counted, being classified either as whole kernel or aborted grains, whose results were used for obtaining sterility percentage. Whole kernel grains were weighted for obtaining the 1000 grains weight for each treatment, and the consequent plant grain yield.

\subsection{Statistical Procedures}

Data were analyzed into the "R" statistical environment ( $R$ Core Team, 2016). The data was submitted to normality (Shapiro-Wilk) and variance homogeneity (Bartlett) tests, at 5\% probability. After removing the outliers, the data was submitted to analysis of variance (Anova) by the F-test at 5\% probability. The number of tillers per plant as a function of days after tillering start an treatment (water stress), was presented with simple regressions, being considered as significantly distinct when its difference was superior to two standard deviations (2sd) of the data set (Peternelli \& Mello, 2011). The variables assessed at the end of the crop cycle were presented in bar graphs and submitted to regression analysis with adjustment of $1^{\text {st }}$ or $2^{\text {nd }}$ degree linear models, being also determined the adjustment coefficient $\left(\mathrm{R}^{2}\right)$. 

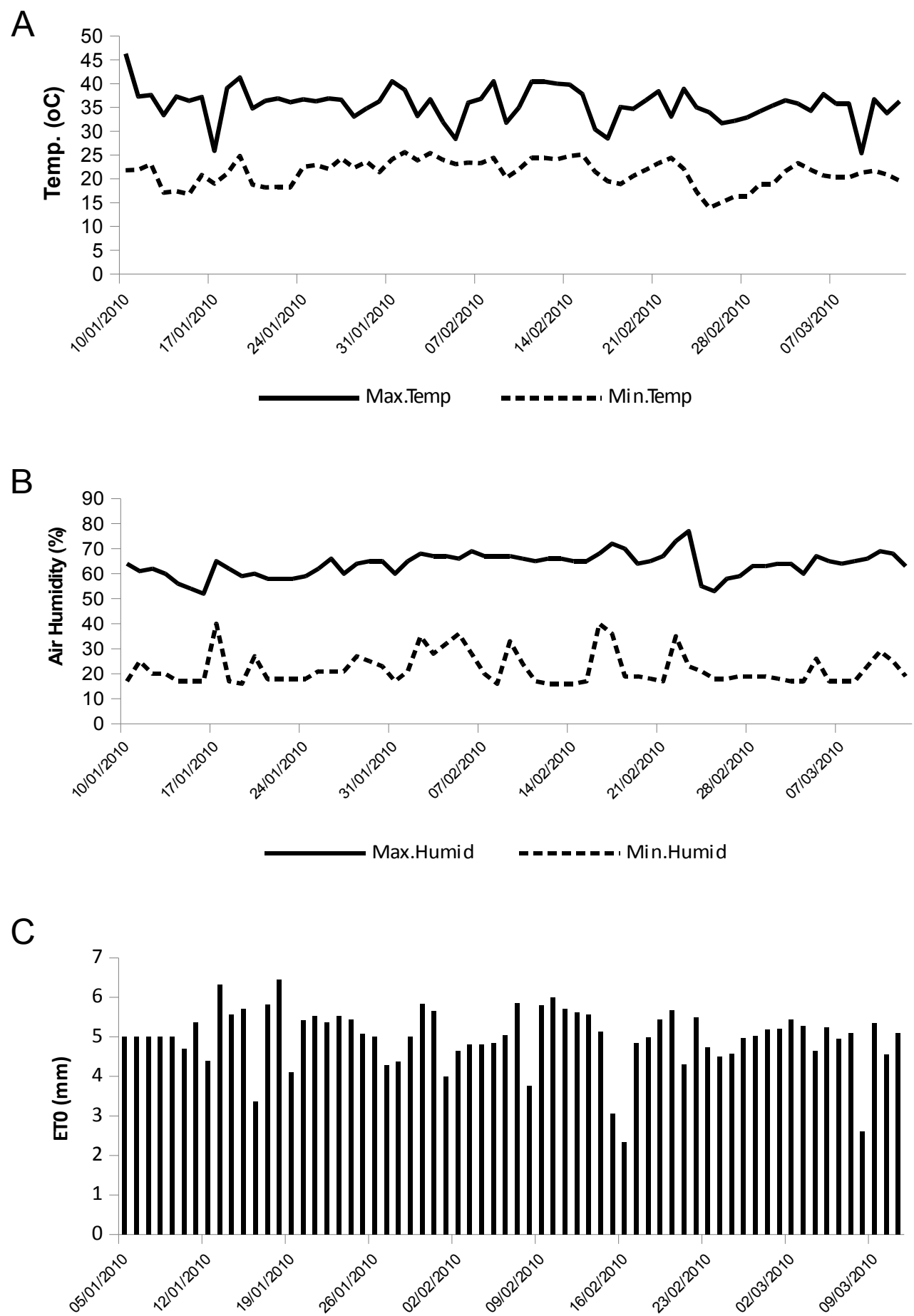

Figure 2. (A) Daily temperature ranges into the greenhouse for ETo estimation; (B) air humidity ranges into the greenhouse along the experiment conduction; (C) Eto calculation by Hargreaves based on daily temperature ranges. Embrapa Clima Temperado, Pelotas-RS, Brazil, 2016

\section{Results and Discussion}

\subsection{Number of Tillers}

The number of tillers per plant was affected by the water stress, but only at the "V" stage (Figure 3), when water tensions of 100 or $200 \mathrm{kPa}$ reduced tillering, respectively, in about 30 and $48 \%$. Under $100 \mathrm{kPa}$, tillering was smoothly recovered after stress was removed, while for $200 \mathrm{kPa}$ no recovery was observed in tillering after the stress was stopped (Figure 3). At the "V" stage, for the flooded check as well as for treatments below $30 \mathrm{kPa}$, 
only the usual tiller mortality by intraspecific competition was reported, being the same observed for the "R1" and "R2" stages. Considering the usual tiller mortality by competition, a maximum of 11-12 tillers was reported per plant, being reduced to 8-9 tillers per plant at the end of the cycle (Figure 3).
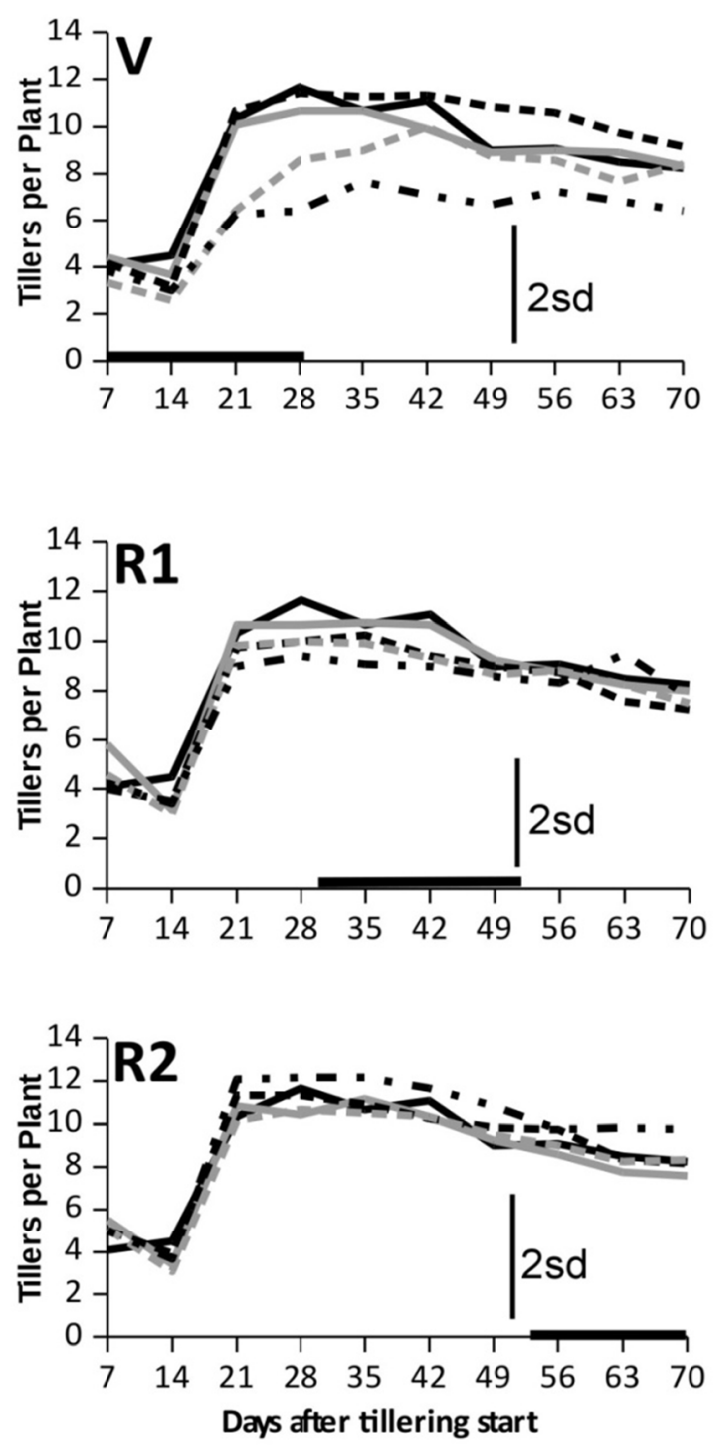

$(\longrightarrow)$ Flood; $(\longrightarrow)$ 10kPa; (-- $) 30 \mathrm{kPa} ;(---)$ 100V/60R kPa; (- '- $)$ 200V/130R kPa

Figure 3. Number of tillers per plant as function of distinct water stress levels imposed to different developmental stages of rice plants cv. BRS-Querencia. Embrapa Clima Temperado, Pelotas-RS, Brazil, 2016

Note. $\mathrm{V}=$ vegetative stage (from tillering start to panicle differentiation); $\mathrm{R} 1$ = reproductive 1 (from panicle differentiation to anthesis); $\mathrm{R} 2$ = reproductive 2 (from anthesis to ripening start).

\subsection{Panicle Number}

As expected, the number of panicles per plant (Figure 4A) was not affected when the water stress was imposed after panicle initiation, since this variable is defined at the vegetative stage, between germination and ten days after panicle primordium is visible (Mauad, Crusciol, Filho, \& Corrêa, 2003). At rice panicle initiation, the number of rice grains per panicle is already biologically defined (Gomes \& Magalhães Jr., 2004). Directly or indirectly, nitrogen fertilization, water stress, environmental conditions and tiller number will define the number 
of panicles per plant (Gomes \& Magalhães Jr., 2004). Thus, water stress at tillering reduced the number of panicles per plant, as previously discussed, being this one of the definers of panicle number.

(A)

Panicles (per plant)

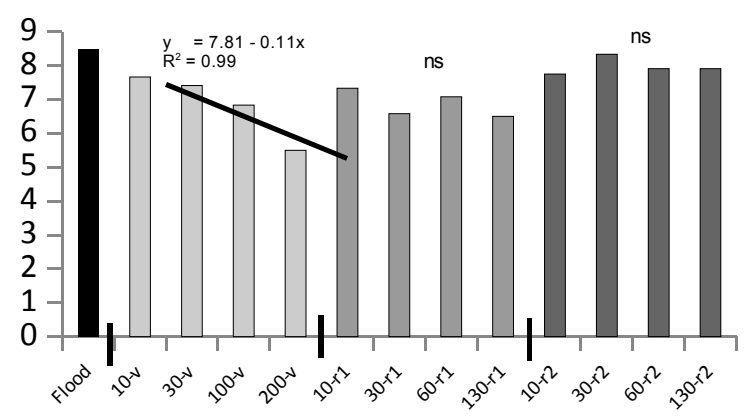

(C)

Aborted grains (per plant)

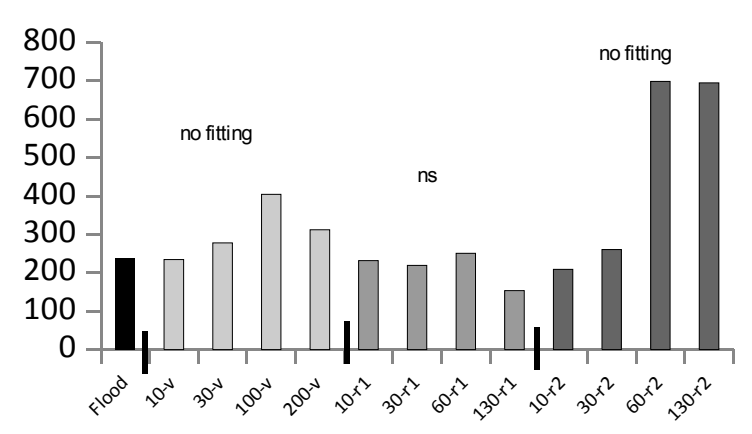

(E)

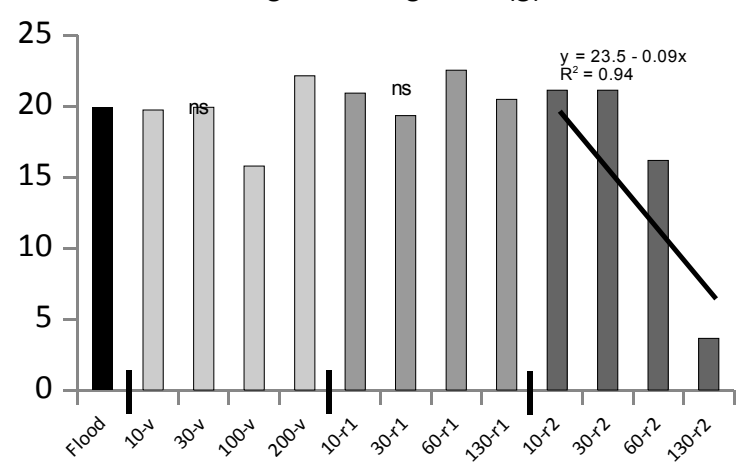

(B) Whole kernel grains (per plant)

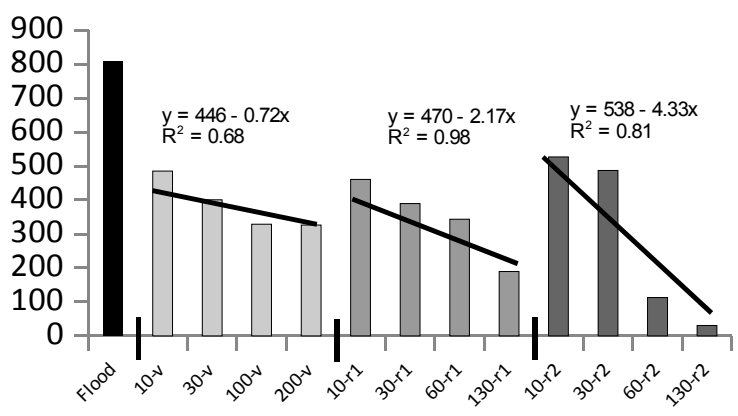

(D)

Grain sterility (\%)

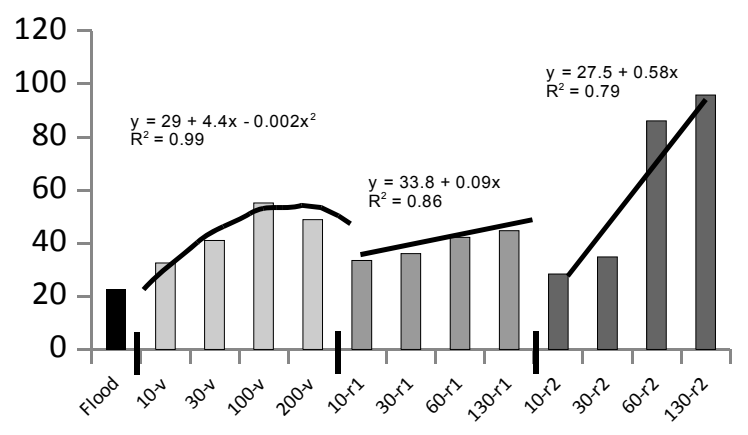

(F)

Grain yield (g per plant)

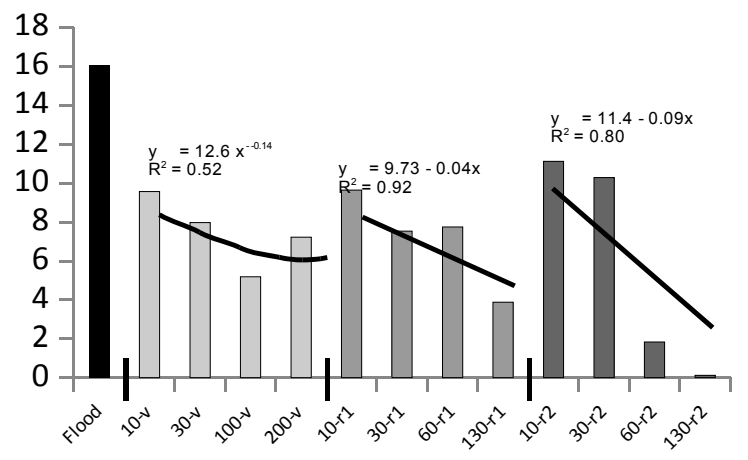

Figure 4. Panicles per plant, grain sterility (\%), weight of 100 grains (g) and rice grain yield $\left(\mathrm{g} \mathrm{plant}^{-1}\right)$ as function of water stress levels imposed at distinct phenological stages under controlled environment

It should be noted also that almost all tillers which were able to survive after the self-thinning (Figure 3), were able to produce a panicle (Figure 4A), being thus the tiller sterility proportion (data not shown) very low. It is estimated that only less than $15 \%$ of the tillers were not able to produce a panicle.

\subsection{Whole Kernel Grains}

The number of whole kernel grains per plant varied among treatments, being the most remarkable different the flooded treatment compared to the other ones (Figure 4B). The flooded check produced about 800 whole kernel grains per plant, while the treatments under $10 \mathrm{kPa}$ averaged about 500 whole kernel grains per plant. The 
damage caused by the stress was clearly as critical as later it was applied; at "V" stage, $200 \mathrm{kPa}$ resulted in about 350 whole kernels per plant, compared to about 500 at $10 \mathrm{kPa}$; at "R1", $130 \mathrm{kPa}$ resulted in about 200 whole kernels, and the same stress imposed at "R2" resulted in only about 50 whole kernels per plant (Figure 4B).

On the other side, the difference between the flooded check and the set of treatments under stress for whole kernels (Figure 4B) was not maintained for aborted grains (Figure 4C), where treatments under 10-30 kPa were similar to the flooded check, with about 240 aborted grains per plant. This supplies evidence that rice grown under water stress (sprinkler or intermittent flooding irrigation) should be planted in higher density compared to continuous flooding as the grain abortion rate is not higher under this irrigation system, but the whole kernel grains are reduced - it should be compensated by a higher tiller (and panicle) density, which may be achieved in the field by using higher seeding rates (Ahmed, Salim, \& Chauhan, 2014) and accurate nitrogen topdressing management (Cai et al., 2006; Parfitt et al., 2017).

\subsection{Grain Sterility}

Rice grains sterility (Figure 4D) was affected by the water stress applied to any developmental stage. At grain filling ("R2"), however, the water stress promoted grains sterility higher than $90 \%$ at stress levels above $60 \mathrm{kPa}$. In fact, grain filling (and consequently grain sterility) is mostly determined between rice crop stages R4 (anthesis) and R9 (harvest), the period when most of the photosynthates are directed to grain filling (Gurevitch et al., 2009). As plants may direct reserves to form roots when under stress (Pascual \& Wang, 2017), for the treatment imposed at "R2" it is likely that there was not enough carbohydrates to fill all rice grains formed during panicle development (rice stages R0 to R4).

Regarding only the filled grains, rice grain weight (Figure 4E) was only reduced where carbohydrates were most probably directed to the primary metabolism aiming survival, and possibly also to root formation in detriment of grain filling (60-130 kPa, applied to the R2 stage). The weight of 1000 grains for Brazilian rice varieties (long and thin grain type) is about 23-30 g (Soares et al., 2010; Leite, Cavalheiro, Schuch, Amaral, \& Tavares, 2011), which was also observed in the present study when the stress was imposed prior to anthesis. When strong stress was imposed at R2, rice grains (1000) weighted less than $5 \mathrm{~g}$, practically halting rice grain yield. In addition, supposing these low weight grains were screened for viability, most of them would probably be sterile (Akil \& Araujo, 1977).

\subsection{Grain Yield}

Rice grain yield is a result of the panicle density, grains per panicle and their weight, which are termed "yield components" (Gomes \& Magalhães Jr., 2004). Lower rice grain yield was observed even when treatments were maintained under $10 \mathrm{kPa}$ all along the crop cycle, compared to the flooded treatment. One have to consider, however, that in studies conducted under controlled environments, treatment effects are usually intensified compared to studies installed in field conditions (Steffen et al., 2010). Thus, these results should be further evaluated in field trials. In addition, by the facts previously mentioned, equivalent grain yield for flooded and sprinkler irrigated fields would most probably be achieved by increasing the seeding rate in sprinkler irrigated fields. Another fact is that rice grain yield, at the vegetative stage, was numerically higher under $200 \mathrm{kPa}$ than under $100 \mathrm{kPa}$. This was attributed to a natural biological variation since the water content in soil under $200 \mathrm{kPa}$ is very similar to the amount available at $100 \mathrm{kPa}$, as shown in the soil retention curve (Figure 1).

\section{Conclusion}

The number of panicles per plant was not affected when stress was imposed after panicle initiation, but when imposed at tillering it reduced the number of panicles per plant. At grain filling ("R2"), water stress promoted grain sterility higher than $90 \%$. Lower rice grain yield per plant was observed even when treatments were maintained below $10 \mathrm{kPa}$ all along the cycle, compared to the flooded treatment.

\section{Acknowledgements}

To Valmont Industries, Irrigation Division, Omaha, NE, USA, for the financial and technical support with data logger hardware that made possible to install the present study.

\section{References}

Ahmed, S., Salim, M., \& Chauhan, B. S. (2014). Effect of weed management and seed rate on crop growth under direct dry seeded rice systems in Bangladesh. PloS One, 9(7), e101919. https://doi.org/10.1371/ journal.pone. 0101919

Akil, B. A., \& Araujo, F. A. X. (1997). Relationships between weight, density, storability and germination characteristics of rice seeds. Ciência Agronômica, 7(1-2), 59-63. 
Cai, Y., Wang, W., Zhu, Z., Zhang, Z., Lang, Y., \& Zhu, Q. (2006). Effects of water stress during grain-filling period on rice grain yield and its quality under different nitrogen levels. Ying Yong Sheng Tai Xue Bao, 17(7), 1201-6.

Carli, C., Steinmetz, S., Streck, N. A., Marchezan, E., \& da Silva, M. R. (2014). Determinação do número de dias e de graus-dia em que a iniciação da panícula (IP) antecede a diferenciação da panícula (DP) em cultivares de arroz irrigado (Circular técnica No. 156, p. 5). Pelotas: Embrapa Clima Temperado.

Gomes, A. S., \& Magalhães Jr., A. M. (2004). Arroz irrigado no sul do Brasil (2nd ed., p. 899). Brasília: Embrapa Informação Tecnológica.

Gurevitch, J., Scheiner, S. M., \& Fox, G. A. (2009). Ecologia vegetal (2nd ed., p. 554). Porto Alegre: Artmed.

Leite, R. F. C., Cavalheiro, R. F., Schuch, L. O. B., Amaral, A. dos S., \& Tavares, L. C. (2011). Rendimento e qualidade de sementes de arroz irrigado em função da adubação com boro. Revista Brasileira de Sementes, 33(4), 599-605. https://doi.org/10.1590/S0101-31222011000400021

Mauad, M., Crusciol, C. A. C., Filho, H. G., \& Corrêa, C. J. (2003). Nitrogen and silicon fertilization of upland rice. Scientia Agricola, 60(4), 761-765. https://doi.org/10.1590/S0103-90162003000400023

Parfitt, J. M. B., Concenço, G., Scivittaro, W. B., Andres, A., Silva, J. T. da, \& Pinto, M. A. B. (2017). Soil and Water Management for Sprinkler Irrigated Rice in Southern Brazil. In J. Li (Ed.), Advances in International Rice Research (pp. 3-18). InTech, Croatia. https://doi.org/10.5772/66024

Parfitt, J. M. B., Pinto, M. A. B., Timm, L. C., Bamberg, A. L., Silva, D. M. da, \& Bretanha, G. (2011). Manejo da irrigação por aspersão e desempenho da cultura do arroz (pp. 461-464). Congresso Brasileiro de Arroz Irrigado, 7. Balneário Camboriú, Itajaí: EPAGRI, SOSBAI.

Pascual, V. J., \& Wang, Y. M. (2017). Impact of water management on rice varieties, yield and water productivity under the system of rice intensification in Southern Taiwan. Water, 9(3), 1-15. https://doi.org/10.3390/ w9010003

Peternelli, L. A., \& Mello, M. P. (2011). Conhecendo o R, uma visão estatística (1st ed., p. 185). Viçosa: UFV.

R Core Team. (2017). R: A language and environment for statistical computing. R Foundation for Statistical Computing, Vienna, Austria. Retrived from https://www.R-project.org

Samonte, S., Wilson, L. T., McClung, A. M., \& Tarpley, L. (2001). Seasonal dynamics of non-structural carbohydrate in 15 diverse rice genotypes. Crop Science, 41(3), 902-909. https://doi.org/10.2135/cropsci 2001.413902x

Soares, E. R., Baseggio, E. A., Londrero, L. da S., Correa, S. C. S., Rossini, V. P., \& Zolinger Galon, L. (2010). Componentes de produção e produtividade de arroz híbrido de sequeiro comparado a três cultivares convencionais. Acta Agronomica, 59(4), 435-441. Retrieved from https://revistas.unal.edu.co/index.php/ acta_agronomica/article/view/20127/21211

Steffen, R. B., Antoniolli1, Z. I., Steffen, K. P. G., Morales, D., Eckhardt, D. P., \& Bassaco, A. C. (2010). Efeitos da creolina sobre a nematofauna associada à cultura do fumo. Tecnológica, Santa Cruz do Sul, 14(1), 20-25. Retrieved from https://online.unisc.br/seer/index.php/tecnologica/article/view/1267/1040

Zain, N. A. M., Ismail, M. R., Puteh, A., Mahmood, M., \& Islam, M. R. (2014). Impacto do estresse hídrico cíclico sobre o crescimento, as respostas fisiológicas e rendimento de arroz (Oryza sativa L.). Ciência Rural, 44(12), 2136-214. https://doi.org/10.1590/0103-8478cr20131154

\section{Copyrights}

Copyright for this article is retained by the author(s), with first publication rights granted to the journal.

This is an open-access article distributed under the terms and conditions of the Creative Commons Attribution license (http://creativecommons.org/licenses/by/4.0/). 